\title{
Agricultural Financing and Economic Growth: A Bayesian VAR Examination of the Nigerian Evidence
}

\author{
James Achumu \\ University of Port Harcourt \\ Ucheoma I. Ezirim \\ University of Port Harcourt \\ Chinedu B. Ezirm \\ University of Port Harcourt \\ Charles Chekwa
Troy University
}

The study attempted to investigate the effects of agricultural financing by both the government and the private sector banks on the gross domestic product of Nigeria, using the Bayesian VAR methodology against annual data from 1981 to 2019. The results indicate that the agriculture credit guarantee scheme funding significantly and positively affects the aggregate national output of Nigeria. The non-governmentguaranteed direct loans and advances from the banks to the agricultural sector significantly and positively affect the aggregate national output of Nigeria. The real contribution of direct government expenditures on the agriculture sector to the gross domestic product is positive, but not significant. The recommendations favor the continuation and strengthening of the ACG Scheme and the encouragement of the relevant development and commercial banks by government and the Central Bank of Nigeria to increase lending to the agricultural sector through moral suasion and deliberate policy.

Keywords: agricultural financing, economic growth, Bayesian VAR, Nigeria

\section{BACKGROUND OF STUDY}

Agriculture is seen as "the backbone of most developing economies", being the source of livelihood of majority of the citizenry of the concerned countries, directly or indirectly. Food security and/or insurance against hunger and poverty are all credited directly to agriculture. For most developing and emerging countries, it is the key source of national income. This may not be absolutely true with the developed countries, where agricultural contribution to income may not be great in comparison. Nonetheless, these developed countries do not neglect this green sector, and remain highly productive, agriculture-wise. It is worth amplifying that income from agricultural exports have assisted many a country to reduce unfavorable 
balance of trade and payment. The guarantee of ample supply of foreign exchange and reserves that accrue from agricultural exports is not to be over-stressed (Dane, 2020; Soken-Huberty, 2021).

It is even posited that proceeds from agricultural exports have assisted many a country to be in the position to import necessary machinery, raw materials, factor inputs, and infrastructure. Its activities help in developing such sectors as the transport sector, since mobility is key to agrarian development. Thus, improvements in such other related sectors derive from the development need and strides of agriculture. Agriculture is, by these tokens, a true catalyst of growth and development. Thus, if agriculture is encouraged and developed, the overall growth and development of the country is greatly ensured. This rests on the argument that agricultural-output-growth-and-development drive economic growth and development, ceteris paribus (Dane, 2020; Soken-Huberty, 2021).

A most veritable route and strategy of ensuring agricultural growth and development in any country is the agricultural financing route. Adequate funding is a sine-qua-non 'necessary and sufficient condition', and in fact, the indispensable avowed natural-route to the developmental- and growth-process of any sector of the economy. Agriculture provides no exception to this rule. Daneji (2011) averred that the development of Nigeria's agricultural sector, aimed at improving the level of agricultural production and to ensure selfsufficiency in food production, is imperative for sustainable national development. That agriculture contributes significantly to the Nigeria's Gross Domestic Product (GDP) is easy to be appreciated when consideration is accorded to its roles in food production, export and foreign exchange potentials, large-scale employment creation and provision, raw materials provision to agro-allied-industries, among others. To say it mildly, agricultural development remains an integral part of national development, and thus, must be consciously encouraged by adequate funding, if the country is serious with growth and development.

Alahira (2020) appears to concur with this point when he submitted that, "agricultural fundings are of utmost importance in the establishment and running of agricultural enterprises". Farm businesses are cardinal, here, to say the least. Agricultural funds are employed for the purchase or lease of farmlands, purchase of farm inputs like seedlings, fertilizer and pesticides and insecticides, hiring and recruitment of farm labor, payment of incidentals and overheads (like maintenance and even fueling of machines), procurement of farm machinery and equipment like tractors and irrigation facilities, and expansion of farm activities (Alahira, 2020). These materialized in the attainment of desired agricultural output growth, and in turn, to the growth of the aggregate national output. Agricultural-output-growth translates to the growth of a nation's gross domestic product, ceteris paribus.

Financing agriculture, unto growth, is matter of deliberate public sector policy and action in partnership with concerted private sector efforts - a case for concerted public-private-partnership (PPP). The government, being the wealthiest economic agent, must take a leading role, while private sector cooperation should naturally follow. The government of Nigeria appeared to have taken concerted initiatives and step in this direction, over the years. This is seen in the year-by-year budgetary allocation to agriculture and attendant direct spending on, and 'investments' in, governmental programs in the sector. The outlay of funds by government directly to agriculture is shown to be $0.013 \mathrm{~b}$ in $1981,0.0157 \mathrm{~b}$ in $1986,7.064 \mathrm{~b}$ in 2001, 41.2b in 2011, 50.26b in 2017, and 58.48b in 2019 (CBN, 2020). The government equally has been in the business of guaranteeing farmers against loans from commercial banks, and these have remained sizable and phenomenally increasing with time. This has been designated as the agricultural credit guarantee funding scheme. For instance, the guaranteed funding grew from 35.6434b in 1981, to 68.4174b in 1986, 728.5454 b in 2001, 10028.989b in 2011, 5849.389b in 2017, and 31873.630b in 2019 (CBN, 2020). Even when these funds are from the banks, the government put forth their guarantee on them, and that is something appreciable.

Banks have not relented in the efforts to fund agriculture with or without the encouragement of the government and policy directions, over the years. The various banks including the Bank of Agriculture, Bank of Industry, commercial banks, and microfinance banks have directly, on their own, and apart from the agricultural credit guaranteed funding, advanced loans to the agricultural sector to the tune of $0.59 \mathrm{~b}$ in $1981,1.83$ b in 1986, 55.84b in 2001, 255.2b in 2011, 528.24b in 2017, and 631.25b in 2019 (CBN, 2020). It is quite commendable that banks have been giving increased attention in the financing of this commanding height of the economy in Nigeria. Notable international development financial institutions 
such as the International Fund for Agriculture and the World Bank have provided some assistance to agriculture in Nigeria, as well. IFAD, for instance, since 1985, has invested a total of US\$317.6 million in ten projects and programs in Nigeria, benefiting more than 3,700,000 households, in their estimation (IFAD, 2021).

The question that needs be asked and answered relates to whether or not the considered efforts of the government, the banks, and other funding agencies have yielded or have been yielding desired boost in agricultural output growth to the point of translating to growth of the gross domestic product of the country as expected or desired. How, for instance, has the combined and disaggregated financing efforts of the government and banks contributed to the growth of aggregate national product? This is an empirical question that requires an empirical answer. The main crux of this study, therefore, is to analyzed in order to determine whether or not, and to what extent, the agricultural financing 'prowls' of the government, directly or indirectly (by way of guaranteed credit) and that of the banks have affected the aggregate national output (GDP) of the Nigeria. To accomplish this objective, use is made of the Bayesian vectorautoregressive (VAR) technique to investigate the effects of government sector and private sector funding of agriculture on the aggregate national output of Nigeria. More specifically, the paper seeks to determine the magnitude and direction of effect of: (i) government direct expenditure on agriculture of the gross domestic product of the country, (ii) the agriculture credit guarantee scheme funding of farmers on the gross domestic product of Nigeria, and (iii) banks' straight loans and advances to the agriculture sector on the gross domestic product of Nigeria.

\section{REVIEW OF RELATED LITERATURE}

\section{Some Conceptual and Theoretical Issues}

Upson (2021) has operational conceptualized the agriculture industry as representing the congeries of 'anything' that is grown or raised for human use; including produce, livestock, flowers, lumber and harvesting plants to sell. The above list implicates that, farmers aren't the only participants in the agriculture industry, although they are the most well-known. Also included are areas that contribute to agriculture, such as biotechnology firms and veterinarians. Florists and nurseries, both of which grow plants to sell, either as plants or as flowers in bouquets, are also a part of the agricultural industry. Wineries may also be considered a part of the agriculture business. The first time that humans traded one agricultural good, such as a pile of corn, for another product marked the beginning of the agribusiness and by extension, the agriculture industry. Agribusiness is used to describe any company that operates within the agriculture industry; and includes not only farms, but the companies that build, sell, and repair the farm equipment, the inspectors that make sure the farm is up to standard and code, and entire milk industry, from the drive that picks up the fresh milk through the driver that delivers the processed milk to the grocery stores, for example. When the agricultural industry is looked at in terms of agribusiness, it is possible to see just how widespread agriculture is, even in modern times (Upson, 2021).

There are the primary and secondary sectors in the agricultural industry. Most of what is produced in the agriculture industry is considered to be in the primary sector, meaning that the original product is straight from nature, and hasn't been changed or processed in any way. Some agricultural products that are processed, such as trees being turned into finished lumber, are considered to be a part of the secondary sector. The agriculture industry has seen a lot of changes in the past 100 years. Agriculturalists can now grow more crops in a smaller amount of space. Although this has made farming cheaper, there have been questions about the ethics involved in raising livestock in tight spaces. Biotechnology has also changed agriculture, by improving soil fertilization, developing larger and hardier crops, and improving the nutrients in harvested food (Upson, 2021).

IFAD (2021) reports that agriculture generated 21 per cent of gross domestic product (GDP) in 2015, but is still underdeveloped because of numerous impediments. These include: Only 46 per cent of arable land is cultivated. Farmers have no title to 95 per cent of agricultural land, so are impeded from obtaining finance or investing in improvements. Poor rural roads undermine farm profitability, increases waste, and impedes access to markets, inputs, equipment and new technology. Rural schools, healthcare and clean 
water supplies are inadequate. Land degradation and erosion arising from over-cultivation, deforestation and overgrazing are increasing, and drought has become common in the northern part of the country.

\section{Financing Options and Government Developmental Programs and Efforts}

Financing agriculture takes a public-private involvement approach. Both the government and the private sector, notably financial institutions, actively participate and cooperate in funding agriculture in Nigeria. The financial institutions can be classified into modern and traditional financial institutions. The modern institutions comprise domestic banking institutions and international development finance institutions. The traditional finance institutions join forces with the government and modern financial institutions in attempt to finance agricultural production and eventual development.

Government funding of Agriculture in Nigeria takes its roots from the annual budgetary and intermittent extra-budgetary provisions made by the government and implemented by the Ministry of Agriculture and National Resources. Through these provisions, government undertake and finance programs and interventions aimed at developing agriculture and boosting its production capabilities in the country. Thus, the central avenue through which the government of Nigeria has contributed its quota in the funding of agriculture is by way of financing agricultural programs and interventions. Through these interventions, huge sums of money have been spent to develop agriculture-based-or-motivated infrastructure, subsidies for fertilizer, improved seedlings, and machinery procurements that are beyond the reach of poor farmers, and a host of others. Direct loans or grants are possible, especially where the government had to pay the farmers for damaged or unsold outputs and many more. It is important to review some of the important programs and interventions in a bid to have a peep into governmental involvement in agricultural funding in Nigeria.

Government's public-private partnership initiative in financing agriculture through the banks is overseen by the central Bank of Nigeria. Three schemes emerge from this financing initiative. The one is the agriculture credit guarantee scheme funding (ACGSF), the Agricultural Credit Support Scheme (ACSS), and the Commercial Agriculture Credit Scheme (CACS). The essence of these interventions is described below; only noting that this study uses the ACGSF to represent all of them, and their total disbursements are lumped together in the ACGSF portfolio, to permit easy analysis (CBN, 2020; 2021a).

Notably, the government has made several efforts to develop agricultural production in the country through a number of policy-bases programs and agency-based interventions. Some of the policy-based programs include the National Accelerated Food Production Program (NAFPP), the Operation Feed the Nation (OFN), the Green Revolution Program (GRP). Agency based interventions include the National Agricultural Land Development Authority (NALDA), River Basin Development Authority (RBDA), Agricultural Development Programs (ADPs) and the Directorate of Food, Road and Rural Infrastructure (DFRRI) (Daneji, 2011).

\section{Review of Previous Empirical Works}

Several works have been carried out in the area of agricultural credit and its relationship with agricultural production or with aggregate national production by several authors and researchers. Some of these works are reviewed hereunder. Şimşir, (2012) examined whether there is a relationship between agricultural growth and economic growth in the long-term and also analyzes whether there is a relationship between agricultural credits as an agricultural support and agricultural growth in the long term. In addition, it is investigated if the agricultural credits are effective for the number of people employed in agriculture. Empirical findings of the study reveal that agricultural credits have a direct effect on agricultural income and employment. On the other hand, agricultural credits have indirect effect on the agricultural income. In their own study,

Chisasa \& Makina (2015) analyzed the dynamic relationship between bank credit and agricultural output in South Africa using time series data from 1970 to 2011. Using the Johansen cointegration test, they uncovered that bank credit and agricultural output were cointegrated. In the long run, credit and capital formation have significant positive impact on agricultural output. The ECM procedure led them to find that, in the short run, bank credit had a negative impact on agricultural output, indicative of the staggering 
uncertainties of institutional credit in South Africa. The ECM parameter signified that agricultural GDP rapidly adjusted to short-term disturbances. The Granger causality tests revealed uni-directional causality from (1) bank credit to agricultural output growth; (2) agricultural output to capital formation; (3) agricultural output to labor; (4) capital formation to credit; (5) capital formation to labor, and a bi-directional causality between credit and labor. From the the results, for the agricultural sector, causality flows from finance to growth, i.e., supply-leading, whereas at the macroeconomic level, causality flowed from economic growth to finance, i.e., demand-leading.

Akinrinola \& Okunola (2020) examined the performance of the Agricultural Credit Guarantee Scheme (ACGS) which is the major credit policy of the Federal Government of Nigeria, which was created in 1977 but started operation in 1978. Time series data from 1978 through 2014 were employed. ARDL (Bounds) test approach to cointegration was employed to investigate both long and short run dynamics of ACGS and agricultural growth. Total volume and number of loans given proxied the ACGS, while the contribution of agriculture to GDP was used to proxy agricultural productivity. Evidence was found for a long-run relationship between total volume of loans, total number of loans and agricultural productivity. In the longrun, the total volume of loans as well as total numbers of loans significantly influenced productivity. In the short run, total volume of loans was not significant with productivity in the current year, but was significant in the previous four years. The total number of loan beneficiaries had a negative but significant relationship with productivity in the past 2 and 3 years while the relationship in the past year was also negative but notsignificant. However, there was a positive and significant relationship between total number of loans issued and productivity in the current year. The speed of adjustment, ECT (-1) value of -0.1991 demonstrated that the model will return to long run equilibrium at the speed of $19.91 \%$ from short run disequilibrium.

Ammani (2012) set out to investigate the relationship between agricultural production and formal credit supply in Nigeria, using simple regression models relating agricultural output with formal credit while holding other explanatory variables constant. Findings of the paper indicated that formal credit was positively and significantly related to the productivity of the crop, livestock and fishing sectors of Nigerian agriculture. Based on the findings it is recommended that government should continue to encourage the expansion of formal credit sources to reach as much farmers as possible. Orok \& Ayim's (2017) study investigated the impact of Agricultural credit Guarantee scheme fund (ACGSF) on Agricultural Sector Development in Nigeria. Specific objectives were to ascertain the relationship between the ACGSF and the output of the crop sector, livestock sector, and fishery sector in Nigeria; measured by respective gross domestic product (GDP). Findings revealed a positive and significant relationship between ACGSF and the agricultural sector development evaluated by the sustained rise in its contribution to GDP. The study also revealed that the scheme had given more funds and impacted more on the crop sector over the livestock and fishery sector.

Danladi, Sale \& Elisha (2019) studied the impact in the agricultural credit guarantee scheme fund on economic growth Nigeria for the period of 1986-2017. The independent variables used included Agricultural Credit Guarantee Scheme fund (AGC), interest rate to agricultural loan (INTRA), Commercial Bank's Credit to the Agricultural Sector (CBC), and Government Financial Allocation to the Agricultural Sector (GFA), while the dependent variable was the Real Economic Growth (RGDP). The Ordinary Least Square (OLS) and granger-causality techniques were employed. The result indicated that a significant relationship existed between AGC and economic growth in Nigeria. While the parameter estimate of INTRA relates positively with GDP but was found statistically not-significant, CBC and GFA posted positive and significant relationships with GDP. Recommendation was that government and the private sectors should invest more in agribusiness to improve domestic supply of food in Nigeria, and Nigerian farmers should also be encouraged to adopt more modern and mechanized systems of farming by providing them with modern farm machinery and implements.

Oguoma, Ben-Chendo \& Henri-Ukoha (2010) reviewed the Agricultural Credit Guarantee Scheme Fund (ACGSF), which was a policy instrument of the Federal Government of Nigeria on Agricultural Credit, and which was established to provide guarantee on loans granted by banks to farmers for agricultural production and agro-allied processing. The paper attempted to review the scheme, its roles since inception, problems and prospects in contributing towards the nation's agricultural development. It was muted that 
"since credit is needed for enhanced productivity and agricultural development, the three tiers of government in Nigeria should give the scheme the necessary support and publicity so that farmers (particularly small farmers) can benefit from its laudable objectives; as this will go a long way in ameliorating the seemingly dismal output of our farmers".

Adejumo \& Omonona's (2017) study analyzed the performance of the scheme in achieving the objective of the scheme, which "is to provide a guarantee on loans granted by banks to farmers for agricultural production thereby developing the agricultural sector in Nigeria". While the supply of credit to farmers by financial institutions has improved since the intervention of the Central Bank of Nigeria who has increased the capital base of the ACGSF, findings revealed that small-scale farmers constituted a low percentage $(21.4 \%)$ of the total number of farmers that received loans under the ACGSF. Also, the bulk of the credit fund is directed towards production of the food crop sector. Their study suggested that a favorable and enabling environment that will increase awareness and accessibility of farmers, especially small-scale farmers, to credit should be created.

A copious revelation from the above studies is the near-absence of sophisticated econometric procedure, beyond regression, to analyze the relationships between agricultural financing, productivity and economic performance. It is implicated to this in a bid to verify if the earlier findings would stand the test of plausibility and veracity. It is in this vein that this study will fill this gap by employment the Bayesian VAR methodology to address the financing-output relationships implicated in the study.

\section{Some Methodological Issues: Bayesian Versus Standard VAR Models}

In Mathworks.com (2021), "a vector autoregression (VAR) model is a system of simultaneous linear equations that describes the evolution of multiple stationary response series. Equations in the system are functions of constants, time trends, lagged responses, and exogenous predictor variables". A Bayesian vector autoregression (VAR) model assumes a prior probability distribution on all model coefficients (AR coefficient matrices, model constant vector, linear time trend vector, and exogenous regression coefficient matrix) and the innovations covariance matrix. When combined with data to form a posterior distribution, this framework can lead to a more flexible model and intuitive inferences. To start a Bayesian VAR analysis, create the prior model object that best describes your prior assumptions on the joint distribution of the coefficients and innovations covariance matrix. bayesvarm creates Bayesian VAR models with a Minnesota prior regularization structure. Then, using the prior model and data, estimate characteristics of the posterior distributions, simulate from the posterior distributions, or forecast responses using the predictive posterior distribution (Mathworks.com, 2021).

Wikipedia (2021) volunteered that Bayesian vector autoregression. In statistics, Bayesian vector autoregression (BVAR) uses Bayesian methods to estimate a vector autoregression (VAR). In that respect, the difference with standard VAR models lies in the fact that the model parameters are treated as random variables, and prior probabilities are assigned to them. In statistics and econometrics, Bayesian vector autoregression (BVAR) uses Bayesian methods to estimate a vector autoregression (VAR) model. BVAR differs with standard VAR models in that the model parameters are treated as random variables, with prior probabilities, rather than fixed values. Vector autoregressions are flexible statistical models that typically include many free parameters. Given the limited length of standard macroeconomic dataset relative to the vast number of parameters available, Bayesian methods have become an increasingly popular way of dealing with the problem of over-parameterization. As the ratio of variables to observations increases, the role of prior probabilities becomes increasingly important (Koop \& Korobilis, 2010)).

The general idea is to use informative priors to shrink the unrestricted model towards a parsimonious naïve benchmark, thereby reducing parameter uncertainty and improving forecast accuracy (Karlsson, 2012). A typical example is the shrinkage prior, proposed by Robert Litterman $(1979,1984)$ and subsequently developed by other researchers at the University of Minnesota (Doan, Litterman \& Sims, 1984; Sims, 1989); (i.e. Sims C, 1989), which is known in the BVAR literature as the "Minnesota prior". The informativeness of the prior can be set by treating it as an additional parameter based on a hierarchical interpretation of the model (Giannone, Lenza, \& Primiceri, 2014). In particular, the Litterman/Minnesota prior considers a normal prior on a set of parameters with fixed and known covariance matrix, which will 
be estimated with one of three techniques: Univariate AR, Diagonal VAR, or Full VAR. Recent research has shown that Bayesian vector autoregression is an appropriate tool for modelling large data sets (Banbura, Giannone \& Reichlin, 2010).

\section{METHODOLOGY}

\section{Design, Procedure, and Data}

The study was basically an econometric study that utilized the Bayesian classical vector autoregression approach to investigate the relationships between the different aspect of agricultural financing and the gross domestic product of Nigeria. Because causal relations are implicated, the study follows the causal comparative research design, with the testing of critical hypotheses as a major aspect of the analysis. In view of the chose classical Bayesian VAR approach, the study specifies the associated models and estimates them using the normal procedure. The selected procedure is to first do a description of the sourced data using pictorial line graph for both the logged-endogenous data and the VAR residual data. The study proceeded to do diagnostic testing of the VAR residuals. Tests of multicollinearity, auto- and serialcorrelation, and heteroscedasticity were adequately carried out and analyzed. Finally, the Bayesian VAR model was estimated under three methods namely Full VAR, univariate AR, and diagonal VAR. Since the critical aim of the study was to determine the degree of influence of the agricultural financing variables on the GDP, then the analysis singled out the relevant aspect of the estimates that appertained to the GDP, and ignored the other aspects that related to the agricultural financing variables.

The data for the study was obtained from the Statistical Bulletin of the CBN for various years and related to the variables namely aggregate national output (GDP), government expenditure on agriculture (GEXA), bank loans and advance, BCLAS, (loans and advances by BOA, BOI, commercial and microfinance banks), and the agriculture credit guarantee scheme fund (ACGSF). These data were converted from their raw form to logarithms to reduce obvious econometric problems. This makes the arising model from these variables to be log-linear or simply linear in logarithms. The data ranged from 1981 through 2019, and n-observation of 39 years.

\section{The Model}

The study hypothesizes that the GDP is a positive function of GEXA, BCLAS, ACGSF; implying that $\mathrm{GDP}=\mathrm{f}($ GEXA, BCLAS, ACGSF).

Further, in view of the autoregressive GEXA nature of the relationships, it is hypothesized that current GDP is a positive function of the past values of itself and those of GEXA, BCLAS and ACGSF, such that

$$
G D P_{t}=\sum_{j=0}^{n} \ln \psi G D P_{t-j}+\sum_{j=0}^{n} \ln \Omega \mathrm{GEXA}_{t-j}+\sum_{j=0}^{n} \ln \varphi \mathrm{BCLAS}_{t-j}+\sum_{j=0}^{n} \ln \phi \mathrm{ACGSF}_{t-j}+\epsilon_{t}
$$

The idea autoregressive effect is that current values of a phenomenon are affected by previous values of the determinants much more than the current values. For instance, it after the government has spent or the banks advanced loans that the real effect will materialize on the GDP, more or less. Transmissions take time. With the above model the autoregressive effects of GEXA, BCLAS and ACGSF on GDP can be determined, alongside own-lagged effects of GDP.

\section{ESTIMATION RESULTS AND DISCUSSION}

\section{Graphical Description of the Variables and Their Residuals}

The data for the current analysis are log-converted from their raw form. The trends in their log-form are represented in Figure 1, while Figure 2 represent the trends in their residuals. As in Figure 1, the endogenous GDP variable at the upper-left hand corner trends up in a much more linear manner without spikes and jumps, climbing upward from left to right, and almost flattening after year 2015. This indicates 
that increases after 2015 to 2019 was minimal, as expected due to the depressive conditions the greeted the Nigerian economy during the period. The bank loans and advances, represented at the lower-left corner, almost followed the same trend as the GDP. It equally sloped upward to the right, but the evident linear growth was minimal during the 2015 - 2019 period, explainable also by the depression the country witnessed at that time. More so, banks in their character are not in a hurry to lend for expansion of activities during depression; instead, they lend for consolidation.

The agricultural credit guarantee scheme funds that were lent to farmers by commercial banks on the strength of government guarantee are represent at the upper-right corner and also sloped upward to the right, but has an upward spike around year 2005/2006, a possible indication of an expected jump in the funding. At the lower-right-hand corner, the trend in government expenditure, GEXA, is represented. The trend follows that of the ACGSF, only that the visible spike occurred around year 2000.

\section{FIGURE 1 \\ VAR ENDOGENOUS GRAPH}
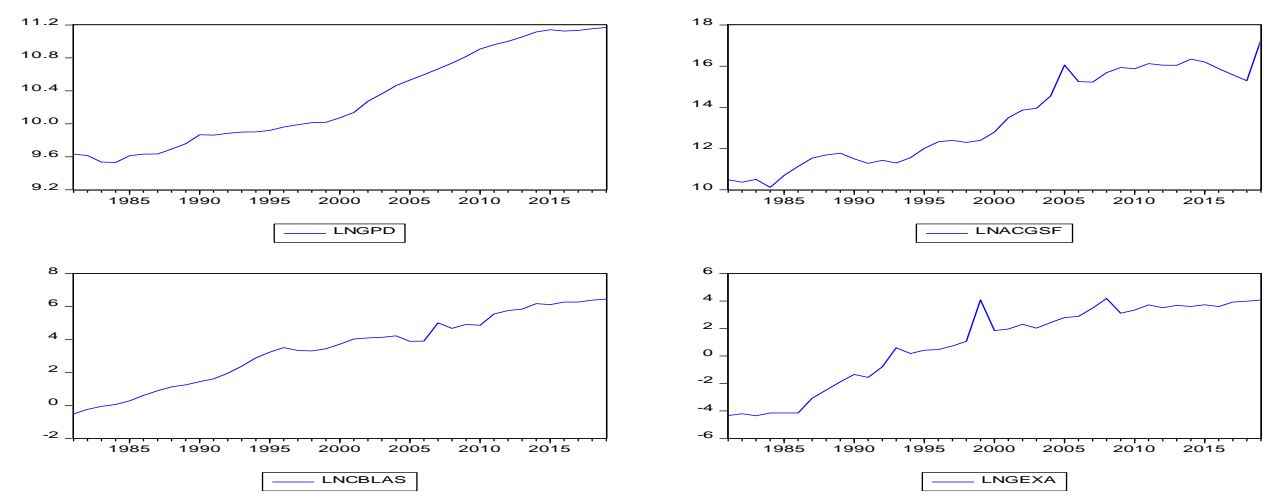

FIGURE 2 VAR RESIDUAL GRAPH
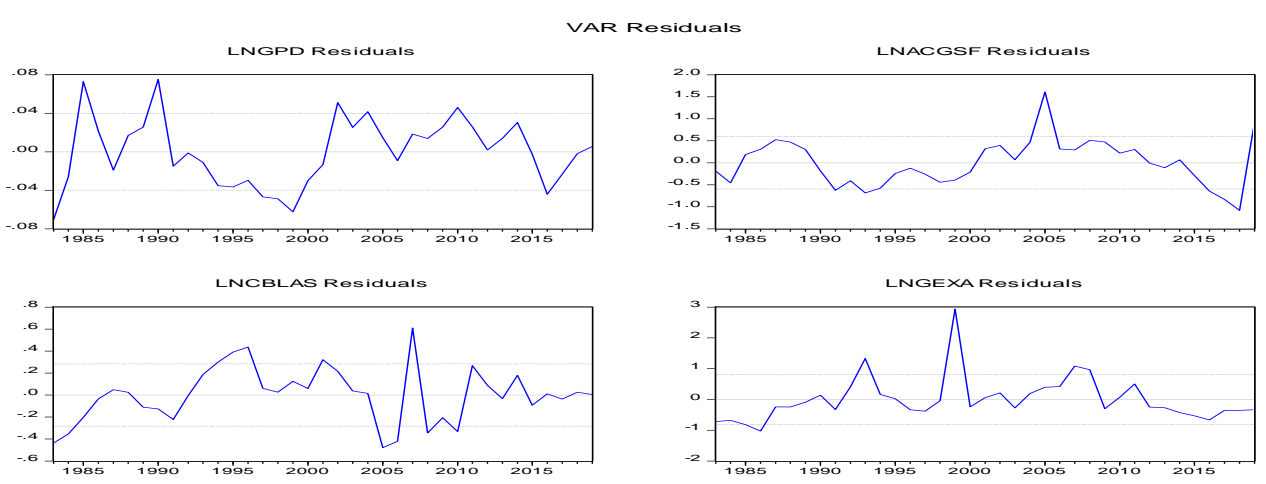

The line graphs of the VAR residuals were more fluctuating with many more spikes than the endogenous graphs, which can be termed smooth, in comparison. The VAR residuals were trending up and down, but not necessarily upward. The highest spikes in the distribution of GDP occurred around 1986 and 2000. The maximum spike occurred around 1986 and followed by 1990 for GDP, while the lowest was in 1999. Or, CBLAS, it was maximum at 1991, but lowest in 2006. ACGSF witnessed its highest point in 2005 and its lowest I 2018. Or GEXA, it was highest in 1998, but was relatively smooth all other periods. It remains to find out what these trends represent in effects of one variable against another. 


\section{Diagnostic Testing of the Bayesian VAR Model}

Tests of Auto- and Serial Correlations

The study proceeded with the estimations by carrying out the diagnostic tests of the VAR model that is specified in section 3.2. Three levels of diagnosis were carried out namely auto- and serial correlations, heteroskedasticity, and multicollinearity. The auto-correlation test utilized the VAR Residual Portmanteau Procedure while the serial correlation test followed the VAR Residual Serial-Correlation LM procedure. The results of the LM test are summarized in Panel A of Table 1, while those of the Portmanteau is summarized in Panel B of the same Table.

TABLE 1

RESULTS OF VAR SERIAL- AND AUTO-CORRELATION TESTS

Panel A: VAR Residual Serial-Correlation LM Tests

Null hypothesis: No serial correlation at lag $\mathrm{h}$

\begin{tabular}{ccccccc}
\hline \hline Lag & LRE* stat & Df & Prob. & Rao F-stat & Df & Prob. \\
\hline \hline 1 & 14.46932 & 16 & 0.5638 & 0.905 & $(16,80.1)$ & 0.5665 \\
2 & 20.03694 & 16 & 0.2186 & 1.295 & $(16,80.1)$ & 0.2212 \\
\hline \hline & & & & & & \\
\hline \hline Lag & LRE* stat & Df & Prob. & Rao F-stat & Df & Prob. \\
\hline \hline 1 & 14.46932 & 16 & 0.5638 & 0.905 & $(16,80.1)$ & 0.5665 \\
2 & 34.33501 & 32 & 0.3564 & 1.088 & $(32,82.7)$ & 0.3702 \\
\hline \hline
\end{tabular}

*Edgeworth expansion corrected likelihood ratio statistic.

Panel B: VAR Residual Portmanteau Tests for Autocorrelations

Null Hypothesis: No residual autocorrelations up to lag $\mathrm{h}$

\begin{tabular}{cccccc}
\hline \hline Lags & Q-Stat & Prob.* & Adj Q-Stat & Prob.* & Df \\
\hline \hline 1 & 9.062135 & --- & 9.307058 & --- & -- \\
2 & 23.07779 & 0.1117 & 24.10136 & 0.0873 & 16 \\
\hline \hline
\end{tabular}

In Panel A of Table 1, the VAR residual serial-correlation LM tests reveal that all the likelihood ratio estimates (LRE*) statistics of 14.47 and 20.04 with probabilities of 0.56 and 0.22 and those of 14.47 and 24.34 with probabilities of 0.56 and 0.36 are all confirmatory that there is no serial correlation at both lag 1 and 2; since the observed probabilities are greater than the critical probability of 0.05 . Equally all the Rao F-statistics of 0.91 and 1.3 with probabilities of 0.57 and 0.22 respectively, as well as those of 0.91 and 1.08 with probabilities of 0.57 and 0.37 respectively at both lag 1 and 2 are also indicative of the absence of serial correlation, since the observed probabilities are greater than the alpha probability of 0.05 . Similarly, in Panel B, VAR residual portmanteau tests for autocorrelations under lags 1 and 2, The QStatistics of 23.08 with a probability of 0.112 under lag 2 and the adjusted Q-statistic of 24.10 with a probability of 0.087 show that there is no problem of residual autocorrelations up to lag 2 . This is because the observed probabilities are greater than the critical alpha probability of 0.05 . Thus, there is no reason to associate the specified VAR model with the problem of serial or autocorrelations among the residuals. The model passes the above tests. 


\section{Tests of Heteroskedasticity}

Table 2 shows the results of the diagnostic tests of heteroskedasticity conducted under condition of no cross terms (levels and squares), depicted on Panel A and under the condition of cross terms as in Panel B.

TABLE 2

RESULTS OF VAR RESIDUAL HETEROSKEDASTICITY TESTS

Panel A: Joint test under no-cross terms (Levels and Sqs)

\begin{tabular}{ccc}
\hline \hline Chi-sq & Df & Prob. \\
78.52915 & 80 & 0.5256 \\
\hline \hline Panel B: Joint test (Includes Cross Terms): & & \\
\hline \hline Chi-sq & Df & \multirow{2}{*}{ Prob. } \\
139.5524 & 140 & 0.4948 \\
\hline \hline
\end{tabular}

In Panel A, the joint test under no-cross terms posts a chi-square of 78.53 with a probability of 0.53 . This observed probability is greater than the alpha probability of 0.05 , and thus suggests that the null hypothesis of "no heteroskedasticity" be accepted. Also, in Panel B, where the Joint test includes cross terms, the observed chi-square of 139.55 has a probability of 0.49 , which is greater than the alpha probability of 0.05 . By implication, the null hypothesis of "no heteroskedasticity" cannot be rejected, but instead accepted. Thus, under both cross- and no-cross terms, the model passes the heteroskedasticity tests.

\section{Test of Multicollinearity}

That the residuals are devoid of multicollinearity is tested using the VAR Residual Correlation Matrix shown in Table 3. A good look at that Table reveals that the correlations of the residuals of the independent variables are all negligible, with the highest being 0.224 (correlating LNCBLAS with LNGEXA). In all cases including the dependent variable, the highest correlation was that relating LNGDP and LNACGSF ( $\mathrm{r}$ $=0.46$ ). These show that the residuals of the variables were not significantly linearly related with each other. They are more or less independent and not multicollinear. This again, shows the model passes the test of multicollinearity.

TABLE 3

\section{VAR RESIDUAL CORRELATION MATRIX}

\begin{tabular}{lcrrr}
\hline Variable & LNGPD & LNACGSF & LNCBLAS & LNGEXA \\
LNGPD & 1.000000 & 0.461724 & -0.109771 & -0.102326 \\
LNACGSF & 0.461724 & 1.000000 & -0.195112 & 0.036512 \\
LNCBLAS & -0.109771 & -0.195112 & 1.000000 & 0.224338 \\
LNGEXA & -0.102326 & 0.036512 & 0.224338 & 1.000000 \\
\hline
\end{tabular}

\section{Analysis of Estimates of the Bayesian VAR Model and Hypotheses Testing}

The Bayesian VAR model specified for this study was estimated using three methods: Univariate AR, Full VAR, and Diagonal VAR. 
TABLE 4

BAYESIAN VAR ESTIMATES

Prior type: Litterman/Minnesota

Initial residual covariance: Univariate AR, Full VAR, and Diagonal VAR

Hyper-parameters: Mu: 0, L1: 0.1, L2: 0.99, L3: 1

Standard errors in ( ) \& t-statistics in [ ]

\begin{tabular}{cccc}
\hline \hline & $\begin{array}{c}\text { Full VAR } \\
\text { LNGPD }\end{array}$ & $\begin{array}{c}\text { Univariate AR } \\
\text { LNGPD }\end{array}$ & $\begin{array}{c}\text { Diagonal VAR } \\
\text { LNGPD }\end{array}$ \\
\hline \hline LNGPD(-1) & 0.838516 & 0.785349 & 0.829449 \\
& $(0.02927)$ & $(0.03724)$ & $(0.02962)$ \\
& {$[28.6455]$} & {$[21.0880]$} & {$[28.0007]$} \\
LNACGSF(-1) & 0.019627 & 0.025834 & 0.021587 \\
& $(0.00525)$ & $(0.00681)$ & $(0.00533)$ \\
LNCBLAS(-1) & {$[3.73530]$} & {$[3.79298]$} & {$[4.04786]$} \\
& & & \\
& 0.021220 & 0.028804 & 0.021859 \\
LNGEXA(-1) & $(0.00761)$ & $(0.00971)$ & {$[0.00772)$} \\
& {$[2.78794]$} & {$[2.96793]$} & {$[2.83298]$} \\
& & & 0.003930 \\
& 0.003903 & 0.003766 & $(0.00349)$ \\
& $(0.00344)$ & $(0.00439)$ & {$[1.12567]$} \\
F-statistic & {$[1.13353]$} & {$[0.85823]$} & 1.428083 \\
& & & $(0.25326)$ \\
C-squared & 1.363259 & 1.801363 & {$[5.63876]$} \\
\hline \hline
\end{tabular}

The full VAR estimates reveal similar global statistics like those of Ful VAR. The coefficient of multiple determination (R-squared) is 0.9965, and after adjusting for the effects of the number of observation and number of predictors, it still remained at approximately 0.9961 . This shows the predictor variables of LNGDP (in this case, the lagged values of LGDP, LNACGSF, LNCBLAS, and LNGEXA) significantly explained about $99 \%$ of the variations in LNGDP. This reveals a very high explanatory power of the model under the Full VAR estimation. This is confirmed by the result of the F-statistic of 2381.667, which is significant at $1 \%$ level, and indicates that the model fits that sourced data very well.

The AR univariate estimation reveal impressive global statistics. The coefficient of multiple determination (R-squared) is 0.9964 , and after adjusting for the effects of the number of observation and number of predictors, it still remained at approximately 0.9959 . This shows the predictor variables of LNGDP (the lagged values of LGDP, LNACGSF, LNCBLAS, and LNGEXA) explaining also about 99\% of the variations in LNGDP. This shows that the model possesses very high explanatory ability under the AR univariate estimation. The result of the F-statistic of 2270.6, which is significant at $1 \%$ level, confirms the high explanatory power of the model, and indicates that it fits the generated data very well.

In the case of the Diagonal VAR estimation global statistics relating to the coefficient of multiple determination (R-squared) is revealed to be 0.9966 , and after adjusting for the effects of the number of 
observation and number of predictors, it still remained at approximately 0.9962. This shows that the predictor variables of LNGDP (the modeled lagged-values of LGDP, LNACGSF, LNCBLAS, and LNGEXA) explain also about $99 \%$ of the changes in LNGDP. Thus, the model reserves very high explanatory ability under the Diagonal VAR estimation. The posted F-statistic of 2424.6 is significant at $1 \%$ level and confirms not only the high explanatory power of the model but also its goodness of fit.

Going by the results of the diagnostic tests as well as the results of the global statistics of the three methods - Univariate AR, Full VAR, and Diagonal VAR-, it is clear that the specified model is globally useful for further analysis and to test the hypotheses implicated in the study. And given the of the VAR estimates, it is clear that the Diagonal VAR possesses the highest explanatory power and makes its estimates the best for further analysis and hypotheses testing.

\section{Tests of Implicated Hypotheses}

Relationship Between GDP and ACGSF

Statement of Hypothesis: The agricultural credit guarantee scheme funds do not significantly affect the aggregate national output of Nigeria.

The above hypothesis is tested using the Diagonal VAR estimates in Table 4. From the Table, the observed beta-coefficient representing the degree of relationship between GDP and lagged-values of ACGSF is 0.021587 , while the associated t-statistic is 4.048 , which is significant at $1 \%$ level. This suggests that the study cannot accept the null hypothesis as stated, but infers that the LNACGSF(-1) variable significantly affects the aggregate national output of Nigeria. Recalling that the observed sign implication of the beta-coefficient is positive, as a priori expected, the variable's effect on the GDP is not only significant but positive. The above finding appears to agree with both Orok \& Ayim's (2017), who found a positive relationship between ACGSF and agricultural production and Danladi, Sale \& Elisha (2019), who found a significant relationship between Agricultural credit guarantee scheme funding and economic growth in Nigeria. Besides, the results of the study verify the development finance theory that finance leads growth, and not versa.

\section{Relationship Between GDP and CBLAS}

Hypothesis: The unguaranteed direct loans and advances from the banks to the agricultural sector do not significantly affect the aggregate national output of Nigeria.

The above hypothesis is also tested using the Diagonal VAR estimates in Table 4. From the Table, the observed beta-coefficient representing the degree of relationship between GDP and lagged-values of CBLAS is 0.021859 , while the associated t-statistic is 2.833 , which is significant at $5 \%$ level. This would make the study not to accept, but instead reject, the null hypothesis as stated above; thus, inferring that the CBLAS(-1) variable significantly affects the aggregate national output of Nigeria. Noting that the observed sign of the beta-coefficient is positive, as a priori anticipated, the variable's effect on the GDP is both significant and positive. The above finding that the unguaranteed direct loans and advances from the banks to the agricultural sector significantly and positively affect the aggregate national output of Nigeria is consistent with the development finance theory that finance leads and causes growth.

\section{Relationship Between GDP and GEXA}

Hypothesis: The direct government financing of agriculture through its budgetary provisions and attendant expenditures does not significantly affect the aggregate national output of Nigeria.

The above hypothesis is tested using the Diagonal VAR estimates in Table 4. From the Table, the observed beta-coefficient representing the degree of relationship between GDP and lagged-values of GEXA 
is 0.00393 , while the associated t-statistic is 1.126 , which is not significant at $5 \%$ level. This would make the study not to reject the null hypothesis as stated above; and thus, inferring that the GEXA (-1) variable does not significantly affects the aggregate national output of Nigeria. Noting that the observed sign of the beta-coefficient is positive, as a priori anticipated, the variable's effect on the GDP is positive but not significant. Thus, the real contribution of direct government expenditures on the agriculture sector is minimal. The above finding raises some worry, especially where consideration is given to the various programs and interventions that the government is identified with in the country over the years. Noteworthy is that given that the observed relation is positive but not significant, the result does not immediately contradict the argument that "finance leads growth", but raises a lot of questions about the manner and direction of government spending on agriculture in Nigeria. Such questions relate to whether or not the spending is optimally channeled to the planned agricultural projects or whether they are diverted to some other unbudgeted avenues. Further inquiries may reveal the true position.

\section{Concluding Remarks \\ Major Findings}

The study highlights the following key findings:

- The agriculture credit guarantee scheme funding significantly and positively affects the aggregate national output of Nigeria.

- The non-government-guaranteed direct loans and advances from the banks to the agricultural sector significantly and positively affect the aggregate national output of Nigeria.

- The real contribution of direct government expenditures on the agriculture sector to the gross domestic product is positive, but not significant.

\section{RECOMMENDATIONS}

From the results of the study, the following recommendations are proffered:

- The agriculture credit guarantee scheme funding should be continued and increased, if development of agriculture is contemplated as important, and if its contribution to aggregate national output is to be realized. Making farmers in every part of the country, and not only those in a particular section of the country, should be started and intensified.

- The Bank of Agriculture, Bank of Industry, and the commercial banks should be encouraged to all the more lend and lend to agriculture without stint, through regular moral suasion and deliberate policy.

- Government spending on agricultural programs and interventions should be more purposeful with a good dose of financial discipline and control.

\section{CONCLUSION}

On the whole, the study finds that agricultural funding boosts the aggregate national output represented by the gross domestic product (GDP) of Nigeria. More specifically, the indirect government-bank partnership funding through the agriculture credit guarantee scheme and the direct bank lending complement to significantly boost the country's GDP. The contribution of the direct government spending on agriculture contributes only minimally.

\section{Limitations of Study}

A study like this needs to corroborate and harmonize the secondary data evidence with primary data perceptions of the real players, the farmers. The, being the direct recipients of the financing are in a good position to give first-hand information about the effectiveness of these funding mechanisms. This is not covered in the present study, and as such be covered in a subsequent work. 


\section{Suggestion for Further Study}

This study should be replicated for other countries in the West African Hemisphere using the Bayesian approach. There is need also to investigate the proposed relationships using causality and cointegration procedures to verify and or validate the approach employed and the results of this study. Survey methodology should also be employed to unravel the impressions of the recipient of the funds on these nominated funding mechanisms.

\section{REFERENCES}

Adejumo, O., \& Omonona, B. (2017). Analysis of the Performance of the Agricultural Credit Guarantee Scheme Fund in Nigeria (1981 to 2016) 1.

Akinrinola, O., \& Okunola, A. (2020). Performance analysis of Nigerian agricultural credit guarantee scheme: Bounds test approach to cointegration. Journal of Development and Agricultural Economics, 12, 75-83.

Alahira, J. (2020). Where to Access Agricultural Funds. Retrieved September 3, 2021, from www.agriculturenigeria.com/manuals/research/articles/

Ammani, A. (2012). An Investigation into the Relationship between Agricultural Production and Formal Credit Supply in Nigeria. International Journal of Agriculture and Forestry, 2, 46-52.

Angaha, J.S., \& Atong, T.A. (2020). Agricultural Financing and Economic Growth in Nigeria: A Threshold Autoregressive (TAR) Analyses. Asian Journal of Agricultural Extension, Economics and Sociology (AJAEES), 38(7), 61-74.

Anthony, E. (2010). Agricultural Credit and Economic Growth in Nigeria: An Empirical Analysis. Business and Economics Journal, 1.

Banbura, T., Giannone, R., \& Reichlin, L. (2010). Large Bayesian vector auto regressions. Journal of Applied Econometrics, 25(1), 71-92. doi: 10.1002/jae.1137

Benmessaoud, R. (2017, March 25). Agriculture: World Banks approved 200M to Nigeria. Vanguard News. Retrieved September 9, 2021, from https://www.vanguardngr.com/2017/03/agriculture

BYJU'S Learning. (2021). Agricultural Development. Retrieved September 7, 2021, from https://byjus.com/commerce/agricultural-development

CBN. (2021). Agric Credit: Agricultural Credit Guarantee Scheme Fund (ACGSF). Retrieved from https://www.cbn.gov.ng/Documents/acgsf.asp

Central Bank of Nigeria. (1998). CBN Annual Agricultural Survey Report (pp. 102-103).

Central Bank of Nigeria. (2020). Annual Agricultural Survey Report. Statistical Bulletin, Abuja: CBN Press.

Chauvin, M. (1993). Development and Cooperatives: Three Decades of Developments Failure, But No Ground for Despair. The Courier, 137, 58-61.

Chisasa, J., \& Makina, D. (2015). Bank Credit and Agricultural Output In South Africa: Cointegration, Short Run Dynamics And Causality. Journal of Applied Business Research, 31, 489-500.

Coursescholars. (2021). Development of Agriculture in Nigeria. Retrieved from https://coursescholars.com/development-of-agriculture-in-nigeria

Dane, K. (2020). Why is Agriculture Important and its Role in Everyday Life? Agriculture Goods. Retrieved from agriculturegoods.com

Daneji, M.I. (2011). Agricultural Development Intervention Programmes in Nigeria (1960 To Date): A Review. Savanah Journal of Agriculture, 6(1), 101-107.

Danladi, G., Sale, Z., \& Elisha, G.A. (2019). Impact of Agricultural Credit Guarantee Scheme Fund on Economic Growth in Nigeria (1986 to 2017).

Doan, T., Litterman, R., \& Sims, C. (1984). Forecasting and conditional projection using realistic prior distributions (pdf). Econometric Reviews, 3, 1-100. doi: 10.1080/07474938408800053

Egwu, P. (2016). Impact of Agricultural Financing on Agricultural Output, Economic Growth and Poverty Alleviation in Nigeria. Journal of Biology, Agriculture and Healthcare, 6, 36-42. 
Erica, P. (2021). Introduction to the fundamentals of vector autoregressive models. Retrieved September 5, 2021, from Introduction to the Fundamentals of Vector Autoregressive Models - Aptech.

Fernando, J. (2021). Gross domestic product (GDP). Retrieved from www.investopedia.com/terms/g/gdp.asp

Giannone, D., Lenza, M., \& Primiceri, G. (2014). Prior Selection for Sector Autoregressions. Review of Economics and Statistics, 97(2), 436-451.

IFAD. (2021). Investing in Rural People: Country facts - Nigeria. Retrieved from https://www.ifad.org/en/web/operations/w/country/nigeria

International Institute of Tropical Agriculture. (1992). IITA in the News. Ibadan, (Jan-June edition), 11.

Jibowo, A.A. (2005). History of Agricultural Extension in Nigeria. Agricultural Extension in Nigeria, p.251.

Karlsson, S. (2012). Forecasting with Bayesian Vector Autoregression. Handbook of Economic Forecasting, 2 B, 791-897. doi:10.1016/B978-0-444-62731-5.00015-4. ISBN 9780444627315

Koop, G., \& Korobilis, D. (2010). Bayesian Multivariate Time-series Methods for empirical macroeconomics (PDF). Foundations and Trends in Econometrics, 3(4), 267-358. CiteSeerX 10.1.1.164.7962. doi:10.1561/0800000013. SSRN 1514412

Litterman, R. (1979). Techniques of forecasting using vector autoregressions. Federal Reserve Bank of Minneapolis Working Paper. no. 115.

Litterman, R. (1984). Specifying VAR's for macroeconomic forecasting. Federal Reserve Bank of Minneapolis Staff Report. no. 92.

Louangrath, P. (2015). Re: Gholia, Renu's Question on: How can I interpret the coefficient units on vertical axis of an Impulse Response Function? Retrieved from https://www.researchgate.net/post/How-can-I-interpret-the-coefficient-units-on

Lu, C., \& Xin, Z. (2010). Impulse-Response function Analysis: An application to macroeconomy data of China. D-level Essay in Statistics, Department of Economics and Society, Högskolan Dalarna, Sweden. Retrieved September 7, 2021, from D10_Xinzhou_lucao.pdf (du.se)

Mafimisebi, E.O. (2008). A Perspective on Partial Credit Guarantee Schemes in Developing Countries: The Case of the Nigerian Agricultural Credit Guarantee Scheme Fund (ACGSF).

Mathworks. (2021). Vector Autoregression Models. Econometris Toolbox Documentation. Retrieved from Vector Autoregression Models - MATLAB \& Simulink (mathworks.com)

Merriam-Webster Dictionary. (2021). Definition of Agriculture. Retrieved from www.merriamwebster.com/dictionary/agriculture

Nath, H.K. (2015). Re: Gholia, Renu's Question on: How can I interpret the coefficient units on vertical axis of an Impulse Response Function? Retrieved from https://www.researchgate.net/post/Howcan-I-interpret-the-coefficient-units-on

National Geographic Society. (2019). The Development of Agriculture. Retrieved from https://www.nationalgeographic.org/article/development-agriculture

Oguoma, N., Ben-Chendo, N., \& Henri-Ukoha, A. (2010). The Agricultural Credit Guarantee Scheme: Its Roles, Problems and Prospects in Nigeria's Quest for Agricultural Development.

Olawoye, J.E., \& Ogunfiditimi, T.O. (1989). Multi-Dimensional Approaches to the Measurement of Development. Technical paper. Dept. of Agric. Extension Services, University of lbadan, p.12.

Omenesa, Z.E. (1991). The Effect of Radio on Agricultural Development in the Northern States of Nigeria. In S.M. Lawani \& T. Babalaye (Eds.), Proceedings of the Workshop on Recent Development in Cereal Production in Nigeria (pp. 63-71).

Oredipe, A. (2016, October 17). World Bank intervention in Nigeria's Agriculture sector hits $\$ 1.5 b n-$ Official. Vanguard News. Retrieved from https://www.vanguardngr.com/2016/10/world-bank

Orok, A.B., \& Ayim, S.A. (2017). The Impact of Agricultural Credit Guarantee Scheme Fund on Agricultural Sector Development in Nigeria. FEN: Experimental Finance (Topic).

Pesaran, M.H., \& Yongcheol, S. (1998). Impulse Response Analysis in Linear Multivariate Models. Economics Letters, 58, 17-29. 
Sims, C. (1989). A nine variable probabilistic macroeconomic forecasting model. Federal Reserve Bank of Minneapolis Discussion Paper. no. 14. Retrieved from http://minneapolisfed.org/research/dp14.pdf

Şimşir, N.C. (2012). An econometric analysis of the relationships between economic growth and agricultural credits for propoor growth in turkey. International Journal of Social Sciences, 4 , 355-364.

Soken-Huberty, E. (2021). 10 reasons why agriculture is important. Retrieved from 10 Reasons Why Agriculture Is Important - The Important Site.

Terzo, G. (2021). What is agricultural development? Retrieved August 30, 2021, from www.infobloom.com/what-is-agricultural-development.html

Ujah, E. (2017, March 25). Agriculture: World Banks approved 200M to Nigeria. Vanguard News. Retrieved September 9, 2021, from https://www.vanguardngr.com/2017/03/agriculture

Upson, M. (2021). What is the agriculture industry? Retrieved August 30, 2021, from www.infobloom.com/what-is-the-agriculture-industry.htm

Wikipedia. (2021a). Agriculture. Retrieved from https://en.wikipedia.org/wiki/Agriculture

Wikipedia. (2021b). Bayesian Vector Autoregressive Models. Retrieved from en.wikipedia.org/wiki/Bayesian_vector_autoregression

Williams, S.K.T. (1981). Structures and Organization of Agricultural Extension Services in Nigeria. An Invited Paper Presented at the Workshop on Utilization of Agricultural Research Results in Nigeria. Bakersu, July 1991.

Wudir, B.B. (1991). Cereals in the Food Economy of Nigeria. In S.M. Lawani \& T. Babaleye (Eds.), Proceedings of the Workshop on Recent Development in Cereal Production in Nigeria (pp. 1325). Ibadan IITA 2-4 Sept. 1991.

Yahaya, M.K. (2000). Indigenous Music for Entertainment-Education: Lessons for AIDS "Batan na ewu eza na" in Bida Emirate Nigeria (p.54). Stirling-Horden Publishers, Ibadan. 